\title{
Interspecific Genome Size and Chromosome Number Variation Shed New Light on Species Classification and Evolution in Caladium
}

\author{
Zhe Cao and Zhanao Deng ${ }^{1}$ \\ University of Florida, Institute of Food and Agricultural Sciences, Environmental Horticulture \\ Department, Gulf Coast Research and Education Center, 14625 County Road 672, Wimauma, \\ FL 33598
}

\author{
Mike Mclaughlin \\ Marie Selby Botanical Gardens, 811 S Palm Avenue, Sarasota, FL 34236
}

\begin{abstract}
Additional INDEX words. Araceae, cytology, genome duplication, nuclear DNA content, polyploidization, taxonomy
Abstract. The genus Caladium Vent. is a member of the family Araceae; some of its species are cultivated as ornamentals. The present study was conducted to determine the genome size, somatic chromosome number, and their variation within 63 accessions representing 10 species of Caladium. Caladium genome sizes estimated using propidium iodide staining and flow cytometry ranged from $2.98 \mathrm{pg} / 2 \mathrm{C}$ in Caladium lindenii Engl. to $9.89 \mathrm{pg} / 2 \mathrm{C}$ in Caladium $\times$ hortulanum Birdsey 'Chang Suek'. Two genome size groups (large and small) were evident among the 63 caladium accessions. The average genome size of 36 caladium accessions in the large genome size group was 9.29 $\mathrm{pg} / 2 \mathrm{C}$, roughly twice that of the 27 accessions in the small genome size group $(4.50 \mathrm{pg} / 2 \mathrm{C})$. Microscopic examination of squashed root tip cells revealed seven somatic chromosome numbers among 39 caladium accessions, including $2 n=18,20,24,26,30,34$, and 38, and provided the first chromosome counts for four caladium species new to Caladium. The results support the species status of $C$. marmoratum Mathieu ex K. Koch, C. picturatum K. Koch \& C.D. Bouché, and C. steudneriifolium Engl. that were merged into C. bicolor (Aiton) Vent. previously and also support the species status of $C$. clavatum Hett., Bogner \& J. Boos, and $C$. praetermissum Bogner \& Hett., two species recently established in or transferred to Caladium. The results suggest that $C$. bicolor and C. schomburgkii Schott, not $C$. picturatum or $C$. marmoratum, are the chief parents of the fancy-leaved caladium (C. Xhortulanum). Four caladium cytotype groups (CCG-1 to -4) were identified in scatterplot of chromosome number vs. genome size. The genome size of $C$. bicolor, $C$. schomburgkii, and $C$. $\times$ hortulanum in the CCG-4 is approximately twice that of $C$. humboldtii (Raf.) Schott and $C$. picturatum in the CCG-2, and the chromosome number of $C$. clavatum and $C$. marmoratum in the CCG-3 is close to twice that of $C$. humboldtii and $C$.picturatum in the CCG-2, both suggesting possible genome duplication or tetraploidization events in Caladium. However, the chromosome number of the CCG-4 species does not correspond to an expected $2 n=36$ or 40 , and the genome size of the CCG-3 species does not correspond to an expected $8.98 \mathrm{pg} / 2 \mathrm{C}$. Conflicts between genome size and chromosome number indicate that genome duplication events were likely followed by chromosome fusions/losses in the formation of CCG-4 species and DNA losses likely followed tetraploidization in the formation of the CCG-3 species. The high level of cytological diversity found within Caladium affects germplasm collection and preservation efforts as well as breeding programs in the genus.
\end{abstract}

Caladium is a member of the family Araceae, belonging to the tribe Caladieae in the subfamily Aroideae (Mayo et al., 1997). The genus is indigenous to the New World tropics, including Brazil, Colombia, Ecuador, Peru, and the West Indies. Like other members of the aroid family, caladiums develop an inflorescence composed of a spadix (an internal spike) and a spathe (an

Received for publication 2 Apr. 2014. Accepted for publication 1 May 2014. We thank the Marie Selby Botanical Gardens for providing access to its collection of caladium species and cultivars and AgriStarts, Inc. for donating caladium tissue culture liners. We thank Dr. Jaroslav Doležel (Laboratory of Molecular Cytogenetics and Cytometry, Institute of Experimental Botany, Olomouc, Czech Republic) for providing seeds of the internal standards for flow cytometry analysis and Alison Yang for help with flow cytometry analysis at the University of Florida/Interdisciplinary Center for Biotechnology Research's Flow Cytometry Core Laboratory in Gainesville, FL. We thank Drs. Kenneth Quesenberry, Richard Henny, and Jianjun Chen for their critical review of the manuscripts and valuable suggestions, and Joyce Jones and Gail Bowman for managing the caladium collection at the Gulf Coast Research and Education Center.

${ }^{1}$ Corresponding author. E-mail: zdeng@ufl.edu. external modified leaf). The spathe is constricted centrally and divided into a lower tube and an upper limb, which unfurls at anthesis, allowing pollinators access to the spadix (Madison, 1981). The spadix consists of fertile male flowers at the top, sterile male flowers (the synandrode) in the middle, and female flowers at the base (Madison, 1981). The fertile male flowers pack tightly on the spadix and the stamens unite into a synandrium; the female flowers consist of only an ovary. The morphologies of inflorescences and flowers are commonly used in defining caladium species. Classification of caladium species and relationships among them have been a subject of debate for decades. The debate mainly concerns the classification of four species, C. bicolor, C. marmoratum, and C. picturatum, and C. steudneriifolium. Madison (1981) merged C. marmoratum, C. picturatum, and C. steudneriifolium into C. bicolor and reduced the number of species in the genus to seven. However, Croat (1994) kept the species status of each of the three species and included 17 species in the genus, and Mayo et al. (1997) reclassified the genus into 12 species (The Plant List, 2013). 
Subsequently two new species, C. clavatum and C. praetermissum, have been added to the genus.

Caladiums were introduced to Europe in the mid-18th century and became a popular hothouse plant there in the 19th century (Hayward, 1950). Caladium breeding was initiated in France in the early 1860s and advanced in Brazil and England in the 1880s (Hayward, 1950; Wilfret, 1993). Since the beginning of the 20th century, caladium breeding has been conducted mainly in Florida, resulting in many new cultivars (Hayward, 1950; Wilfret, 1993). For the last several decades, Florida has become the leading producer of caladium tubers, supplying as much as $95 \%$ of tubers used in pot plant production and landscapes worldwide. In recent years, caladium breeding is active in several other countries, especially in Thailand. Considering the possible hybrid origin of many caladium cultivars, Birdsey (1951) proposed the species name Caladium $\times$ hortulanum for fancyleaved caladium. Little information is available in the literature about the parentage of fancy-leaved caladium cultivars that were produced in other countries or those produced in Florida before 1976. The species that contributed to the development of caladium cultivars have been largely a matter of speculation. Caladium bicolor and $C$. marmoratum were thought to be the chief parent of fancy-leaved cultivars (Hayward, 1950; Wilfret, 1993), and C. picturatum or C. schomburgkii were suspected to provide the lanceolate leaf trait in some caladium cultivars (Graf, 1976; Hayward, 1950; Huxley et al., 1992; Wilfret, 1993).

In caladium taxonomy, morphological and anatomical differences are the primary basis for species classification. The characteristics commonly examined in caladium include floral and inflorescence morphologies, leaf shape and coloration pattern, and tuber morphology. Cytogenetic information such as chromosome number has not been used in the classification of caladium species, presumably as a result of the lack of such information. Although early chromosome counts exist in caladium (Kurakubo, 1940), chromosome numbers are not available for most caladium species according to the Index to Plant Chromosome Numbers [IPCN (Goldblatt and Johnson, 1979)]. In other plants, chromosome numbers have been used in cytotaxonomy (Guerra, 2008) and they have provided key evidence for redefining species boundaries or detecting misclassified species in some aroids (Petersen, 1989). Needless to say, information about chromosome number is useful for plant breeders to devise breeding strategies for introgressing traits through interspecific hybridization.

In recent years, there has been a rapid increase in the number of genome size estimates for many plant species. Such information is scarce for aroids, especially for caladiums (Bennett and Leitch, 2012). Knowledge of genome size is considered critical for many fields of research, including taxonomy and evolutionary studies (Doležel et al., 2007). For example, interand intraspecific genome size variation can complement chromosome counts and reveal taxonomic heterogeneity and incipient speciation (Loureiro et al., 2010). Genome size comparisons, based on nuclear DNA content and increasingly based on DNA sequencing data, have provided evidence for ancient genome-wide duplications in a diverse array of plants (Cui et al., 2006).

The objectives of this study were to document the chromosome numbers and genome sizes of caladium accessions representing 10 species and to pursue a better understanding of the variation in chromosome number and genome size in relation to caladium taxonomy and evolution.

\section{Materials and Methods}

Plant materials. Sixty-three caladium accessions were sampled from three sources, the caladium collection maintained at the University of Florida's Gulf Coast Research and Education Center (UF/GCREC, Wimauma, FL), the Marie Selby Botanical Gardens (MSBG, Sarasota, FL), and AgriStarts, Inc. (Apopka, FL). The UF/GCREC collection consists primarily of C. Xhortulanum cultivars but also several species accessions transferred from the MSBG more than 15 years ago and several accessions from a private owner in Tampa, FL. This collection has been asexually propagated annually through tuber division and grown under field conditions following the production practices described by Deng and Harbaugh (2006). To produce fresh leaf tissue for genome size determination and root tips for chromosome counts, tubers of the UF/GCREC caladium accessions were planted individually in plastic containers $(20 \mathrm{~cm}$ in diameter) filled with the Fafard 3B mix (Conrad Fafard, Agawam, MA), fertilized with $15 \mathrm{~N}-3.9 \mathrm{P}-10 \mathrm{~K}$ controlledrelease fertilizer (Osmocote 15-9-12; Scotts, Marysville, $\mathrm{OH}$ ), and grown in a greenhouse at the UF/GCREC. Temperature in the greenhouse was maintained between 23 and $30{ }^{\circ} \mathrm{C}$ with cooling pads and fans. The MSBG collection consisted of caladiums collected from a number of South and Central American countries over the past 35 years. This collection, arguably the largest collection in North America, represents 10 species with a diversity of plant and foliar characteristics (Fig. 1). Plants were grown individually in plastic containers and maintained in a greenhouse at the MSBG. Seven caladium accessions were kindly provided by AgriStarts, Inc.

Genome SIZE Determination. A flow cytometer (Accuri C6; BD Biosciences, San Jose, CA) equipped with a 488-nm laser light source at the University of Florida's Interdisciplinary Center for Biotechnology Research (Gainesville, FL) and the protocol recommended by Doležel et al. (2007) were used to determine genome sizes. Following the suggestions of Doležel et al. (2007), preliminary experiments were conducted to choose appropriate nuclei extraction buffers and suitable internal standards. The use of LB01 lysis buffer resulted in stable, sharp fluorescence peaks for 'Red Flash' caladium and all internal standards tested. Subsequently this buffer was used for all caladium samples. The buffer consisted of $15 \mathrm{~mm}$ Tris, $2 \mathrm{~mm}$ $\mathrm{Na}_{2}$ EDTA, $0.5 \mathrm{~mm}$ spermine tetrahydrochloride, $80 \mathrm{~mm} \mathrm{KCl}$, $20 \mathrm{~mm} \mathrm{NaCl}$, and $0.1 \%(\mathrm{v} / \mathrm{v})$ Triton X-100 (Sigma-Aldrich, St. Louis, MO). It was adjusted to $\mathrm{pH} 7.5$ and filter-sterilized. Before use, $\beta$-mercaptoethanol was added to the buffer to a final concentration of $15 \mathrm{~mm}$. We chose rye [Secale cereal 'Daňkovské' (16.19 pg/2C)] out of five plant species tested as the internal standard because its fluorescence value was $\approx 1$.7to 3 -fold greater than that of $C$. $\times$ hortulanum 'Red Flash' or $C$. picturatum S2, respectively, and satisfied the normal difference range between sample and standard peaks (Doležel et al., 2007). In addition, rye is a monocot, which might better reflect the DNA configuration in caladium, a monocot also (Praça-Fontes et al., 2011; Suda and Leitch, 2010).

Fresh leaf tissue $(\approx 30 \mathrm{mg})$ was cochopped with a similar amount of leaf tissue from the internal standard in $1 \mathrm{~mL}$ of cold LB01 lysis buffer. The nuclei suspension was filtered through a 50- $\mu$ m nylon filter; the DNA fluorochrome propidium iodide (Sigma-Aldrich) and RNase (Sigma-Aldrich) were added to the nuclei suspension both to a final concentration of $50 \mu \mathrm{g} \cdot \mathrm{mL}^{-1}$. The stained nuclei suspension was incubated at room temperatures 


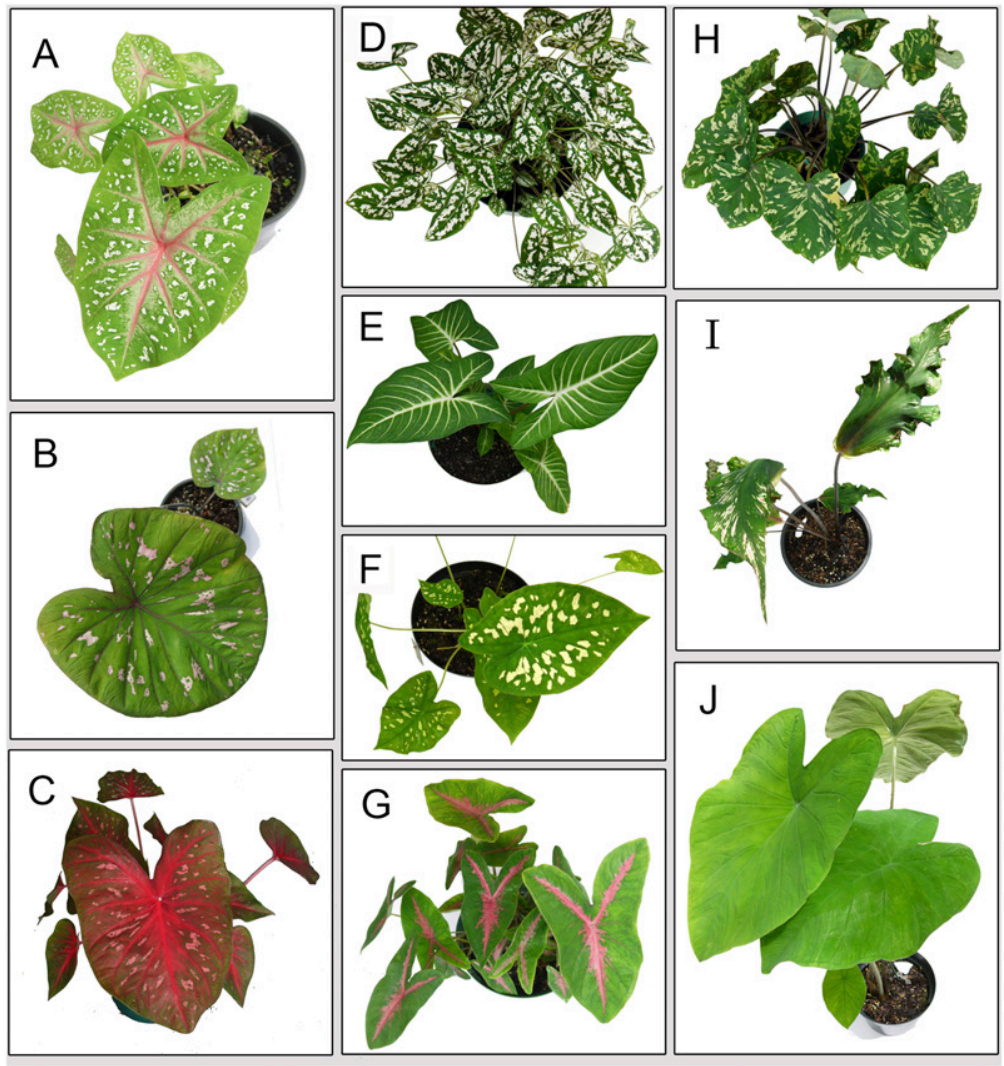

Fig. 1. Top views of 10 caladium accessions grown in containers that represent 10 Caladium species. (A) C. bicolor accession 1997-0278, (B) C. clavatum accession 1977-1576, (C) C. $\times$ hortulanum 'Aaron', (D) C. humboldtii 'Mini White', (E) C. lindenii accession 1986-0736A, (F) C. marmoratum accession 2000-0005A, (G) C. picturatum accession S2, (H) C. praetermissum 'Hilo Beauty', (I) C. schomburgkii accession 2001-0128, and (J) C. steudneriifolium accession 1981-0132A.

were slightly heated over an alcohol lamp to increase the contrast between cytoplasm and chromosome staining. The prepared slides were examined on a light microscope (BH-2; Olympus, Tokyo, Japan), and root tip cells with darkly stained, well-spread chromosomes were photographed on a microscope (BX41; Olympus) under a $100 \times$ objective (UPlan F1; Olympus) and a digital camera (Q-Color 5; Olympus).

\section{Results}

Genome size estimates. The described flow cytometry protocol yielded high-resolution histograms for caladium samples. The $\mathrm{CV}$ values for all caladium accessions were generally below $2 \%$ and never over $5 \%$. SD values for mean genome size estimates for the great majority of caladium accessions were $0.09 \mathrm{pg}$ or less, except for two accessions ('Cense' and BTR1), whose SD values were 0.29 and 0.55 pg, respectively (Table 1).

Table 2 presents the mean genome size estimates for 63 caladium accessions grouped by species. Caladium genome size estimates ranged from $2.98 \mathrm{pg} / 2 \mathrm{C}$ in $C$. lindenii (19860736A) to $9.89 \mathrm{pg} / 2 \mathrm{C}$ in $C$. Xhortulanum 'Chang Suek' (i.e., greater than 3-fold difference among caladium species in genome size). When genome size estimates were displayed in a scatterplot, two groups were identified (Fig. 2). Group 1 (large genomes) consisted of 36 accessions including all the fancyleaved caladium cultivars (C. $\times$ hortulanum),

for $2 \mathrm{~min}$ before it was fed into the flow cytometer. For each accession, at least three runs were performed, and for each flow cytometer run, at least 3000 nuclei were counted. Genome size of caladium samples was calculated according to Doležel et al. (2007): sample genome size $=$ genome size of internal standard $\times$ (mean fluorescence value of sample/mean fluorescence value of internal standard). Intraspecific genome size variation was calculated according to Leong-škorničkova et al. (2007): intraspecific variation $=[$ (largest genome size value within species - smallest genome size value within species)/smallest genome size value within species] $\times 100$. All calculations were done in the computer program Excel ${ }^{\circledR} 2011$ (Microsoft Corp., Redmond, WA).

Chromosome counting. Actively growing root tips $(\approx 4 \mathrm{~mm}$ long) were collected from container-grown caladium plants at the UF/GCREC or the MSBG, placed in 0.02 M 8-hydroxyquinoline solution (a mitotic inhibitor) for $3 \mathrm{~h}$ in dark (pretreatment), and fixed in a fixative solution ( 3 methanol:1 acetic acid, v/v) overnight. Fixed root tips were digested in $1 \mathrm{~N} \mathrm{HCl}$ solution at room temperatures $\left(\approx 24{ }^{\circ} \mathrm{C}\right)$ for $20 \mathrm{~min}$, rinsed with deionized water three times, and stained overnight in 1 to $3 \mathrm{~mL}$ of the acetocarmine solution (84-1423; Carolina Biological Supply Co., Burlington, NC). The root tip was placed on a clean glass slide in a drop of aceto-carmine, and the root cap and the tissue behind the meristematic tip were removed using a scalpel. A glass coverslip was gently placed over the meristematic tip using a pair of tweezers, and the root tip was squashed with a thumb. Slides all $C$. schomburgkii accessions, and all but one $C$. bicolor. Group 2 (small genomes) included one $C$. bicolor accession (1983-0353) and all accessions of C. clavatum, C. humboldtii, C. lindenii, C. marmoratum, C. picturatum, C. praetermissum, and $C$. steudneriifolium. The genome size of caladium accessions in Group 1 was between 8.77 pg/2C (in 'Cense') and 9.89 pg/2C (in 'Chang Suek'), and the genome size of caladium accessions in Group 2 was between 2.98 pg/2C (in C. lindenii 1986-0736A) and $5.58 \mathrm{pg} / 2 \mathrm{C}$ in $C$. marmoratum 2000-0005A. The average genome size of Group 1 and Group 2 caladium accessions was 9.22 and $4.50 \mathrm{pg} / 2 \mathrm{C}$, respectively. That is, the average genome size of Group 1 caladium accessions was approximately twice the average genome size of Group 2 caladium accessions.

Intraspecific genome size variation was very small (less than $3 \%$ difference between the smallest and the largest genomes) in five species: C. clavatum, $C$. lindenii, $C$. marmoratum, $C$. praetermissum, and $C$. schomburgkii. Larger intraspecific genome size variations were observed in $C$. Xhortulanum $(12.8 \%)$, C. humboldtii $(9.2 \%)$, and $C$. picturatum $(6.0 \%)$. In $C$. $\times$ hortulanum, 22 of 26 cultivars had genome sizes between 9.00 and $9.47 \mathrm{pg} / 2 \mathrm{C}$, but three cultivars had a genome size of $\approx 8.80 \mathrm{pg} / 2 \mathrm{C}$, and one cultivar had a genome size of $9.98 \mathrm{pg} / 2 \mathrm{C}$. 'Candidum' and 'Triomphe de l'Exposition', two fancy-leaved caladium cultivars developed in France in $\approx 1880$ and $\approx 1860$, respectively, had similar genome sizes; but four of the eight Thai lance-leaved cultivars showed large variations in genome size. Of the three C. humboldtii accessions tested, 'Mini White' had 


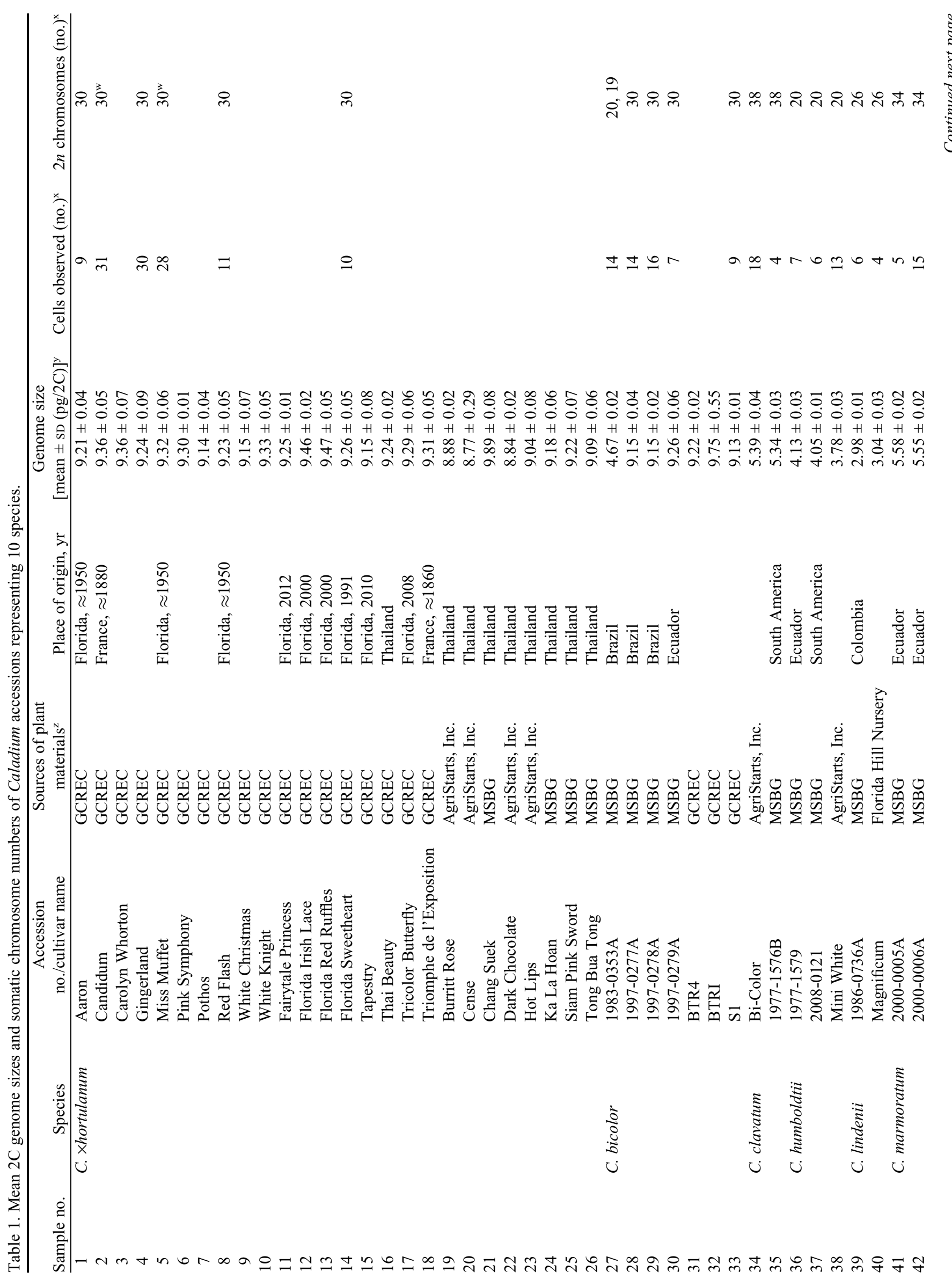




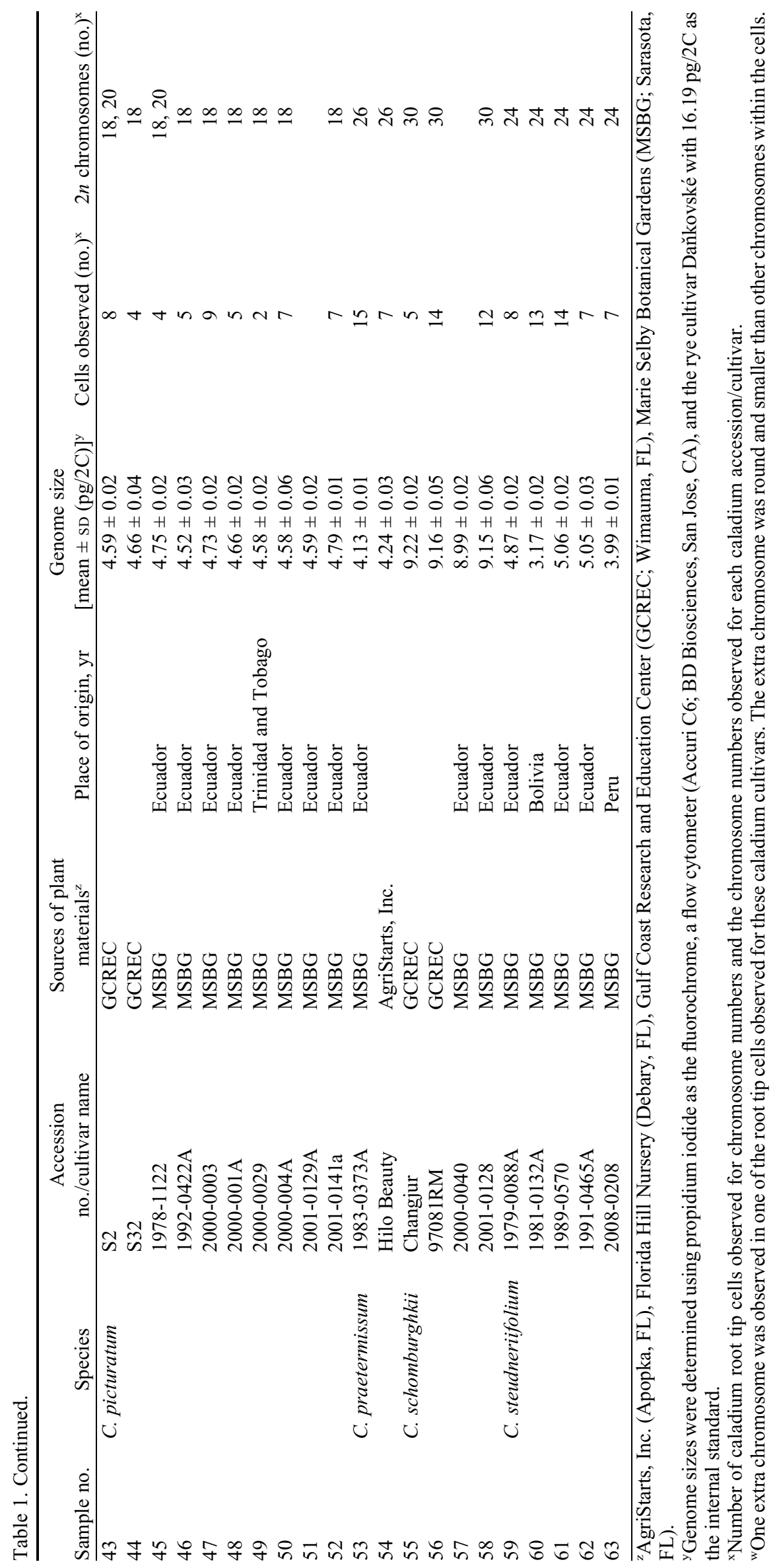


Table 2. Summary of ranges and averages for $2 \mathrm{C}$ genome size and chromosome number of Caladium species and caladium cytotype groups (CCG).

\begin{tabular}{|c|c|c|c|c|c|c|c|}
\hline$\underline{S p e c i e s}^{z}$ & $\begin{array}{c}\text { Accessions } \\
\text { sampled }^{\mathrm{z}}\end{array}$ & $\begin{array}{c}\text { Genome size } \\
\text { range }(\mathrm{pg} / 2 \mathrm{C})^{\mathrm{y}}\end{array}$ & $\begin{array}{l}\text { Avg genome } \\
\text { size }(\mathrm{pg} / 2 \mathrm{C})^{\mathrm{y}}\end{array}$ & $\begin{array}{c}\text { Genome size } \\
\text { variation }(\%)^{\mathrm{y}}\end{array}$ & $\begin{array}{c}\text { Root tip cells } \\
\text { observed (no.) }^{\mathrm{x}}\end{array}$ & 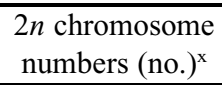 & $\begin{array}{l}\mathrm{CCG} \\
\text { no. }^{\mathrm{w}} \\
\end{array}$ \\
\hline C. $\times$ hortulanum & 26 & $8.77-9.89$ & 9.22 & 12.8 & 119 & 30 & 4 \\
\hline C. bicolor excluding 1983-0353A & 6 & $9.13-9.75$ & 9.28 & 6.7 & 46 & 30 & 4 \\
\hline C. clavatum & 2 & $5.34-5.39$ & 5.37 & 0.9 & 22 & 38 & 3 \\
\hline C. humboldtii & 3 & $3.78-4.13$ & 3.99 & 9.2 & 26 & 20 & 2 \\
\hline C. lindenii & 2 & $2.98-3.04$ & 3.01 & 2.0 & 10 & 26 & 1 \\
\hline C. picturatum & 10 & $4.52-4.79$ & 4.65 & 6.0 & 51 & 18 & 2 \\
\hline C. praetermissum & 2 & $4.13-4.24$ & 4.19 & 2.6 & 22 & 26 & 1 \\
\hline C. schomburghkii & 4 & $8.99-9.22$ & 9.13 & 2.5 & 31 & 30 & 4 \\
\hline C. steudneriifolium & 5 & $3.17-5.06$ & 4.43 & 60 & 49 & 24 & 1 \\
\hline CCG-1 & 9 & $2.98-5.06$ & 4.06 & 69.8 & 81 & 24,26 & \\
\hline CCG-2 & 14 & $3.78-4.79$ & 4.51 & 26.7 & 91 & 18,20 & \\
\hline
\end{tabular}

${ }^{\mathrm{z}}$ Caladium species and number of accessions were sampled.

${ }^{\mathrm{y}}$ Genome size range values were listed from the lowest to the highest within species or cytogroups; average genome sizes were calculated by dividing the sum of the sampled genome size values by the number of accessions within species or cytogroups; and genome size variation was calculated by the formula: [(largest genome size value within species - smallest genome size value within species)/smallest genome size value within species] $\times 100$.

${ }^{x}$ Cells observed and chromosome counts within species or cytogroups.

${ }^{\mathrm{w}}$ Caladium cytotype number determined by genome size and chromosome count (Fig. 4).

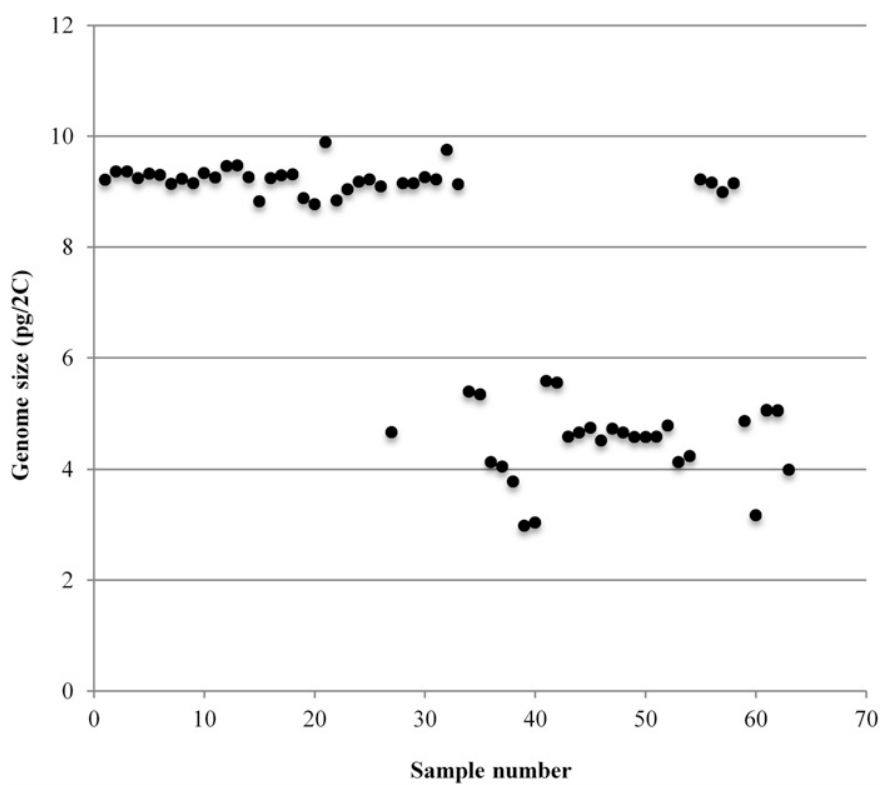

Fig. 2. Scatterplot of genome size estimates for 63 caladium accessions representing 10 Caladium species, indicating two major groups of genome sizes. The large genome size group is comprised of 36 caladium accessions with a genome size between 8.77 to $9.89 \mathrm{pg} / 2 \mathrm{C}$, and the small genome size group consists of 27 caladium accessions with a genome size between 2.98 to $5.59 \mathrm{pg} / 2 \mathrm{C}$.

the smallest genome size and was the main cultivar causing the intraspecific genome size variation. Within C. picturatum, genome size varied from 4.52 to $4.79 \mathrm{pg} / 2 \mathrm{C}$ and averaged 4.65 $\mathrm{pg} / 2 \mathrm{C}$ for the 10 accessions tested.
Intraspecific genome size variation was large in C. steudneriifolium and C. bicolor, reaching 60\% and 108\%, respectively. Three C. steudneriifolium accessions (1979-0088A, 1989-0570, and 1991-0465A) collected from Ecuador exhibited a similar genome size, 4.87 to $5.06 \mathrm{pg} / 2 \mathrm{C}$, whereas the two accessions from Bolivia and Peru displayed a smaller and more divergent genome size, $3.17 \mathrm{pg} / 2 \mathrm{C}$ for 1981-0132A (Bolivia) and 3.99 $\mathrm{pg} / 2 \mathrm{C}$ for 2008-0208 (Peru). In C. bicolor, one of the seven accessions (1983-0353A) had a genome size approximately half the genome size $(4.67 \mathrm{pg} / 2 \mathrm{C})$ of other accessions (9.13 to $9.75 \mathrm{pg} / 2 \mathrm{C})$.

Chromosome counts. A total of 410 cells with well-spread chromosomes was identified from root tip cell squashes observed under the microscope at $1000 \times$ magnification. Chromosome counts were obtained from at least seven cells for each of 39 accessions across 10 caladium species. Seven chromosome numbers $(2 n=18,20,24,26,30,34$, and 38) were observed in these accessions (Table 1; Fig. 3 ).

All six C. $\times$ hortulanum cultivars (Aaron, Candidum, Florida Sweetheart, Gingerland, Miss Muffet, and Red Flash) had $2 n=$ 30 chromosomes. One extra chromosome was observed in one cell of the 'Candidum' and 'Miss Muffet' each. The extra chromosome in both cells was nearly round and smaller than the other chromosomes (photos not shown). Four C. bicolor accessions (1997-0277A, 1997-0278A, 1997-0279A, and S1) had $2 n=30$ chromosomes. Caladium bicolor 1983-0353A was an exception, which had $2 n=20$ chromosomes and a markedly smaller genome size than other $C$. bicolor accessions. Aneuploid cells with $2 n=19$ were observed in some root tip cells of accession 1983-0353A. Four C. schomburgkii accessions, 97081RM, 2000-0040, 2001-0128, and 'Changjur', shared the 

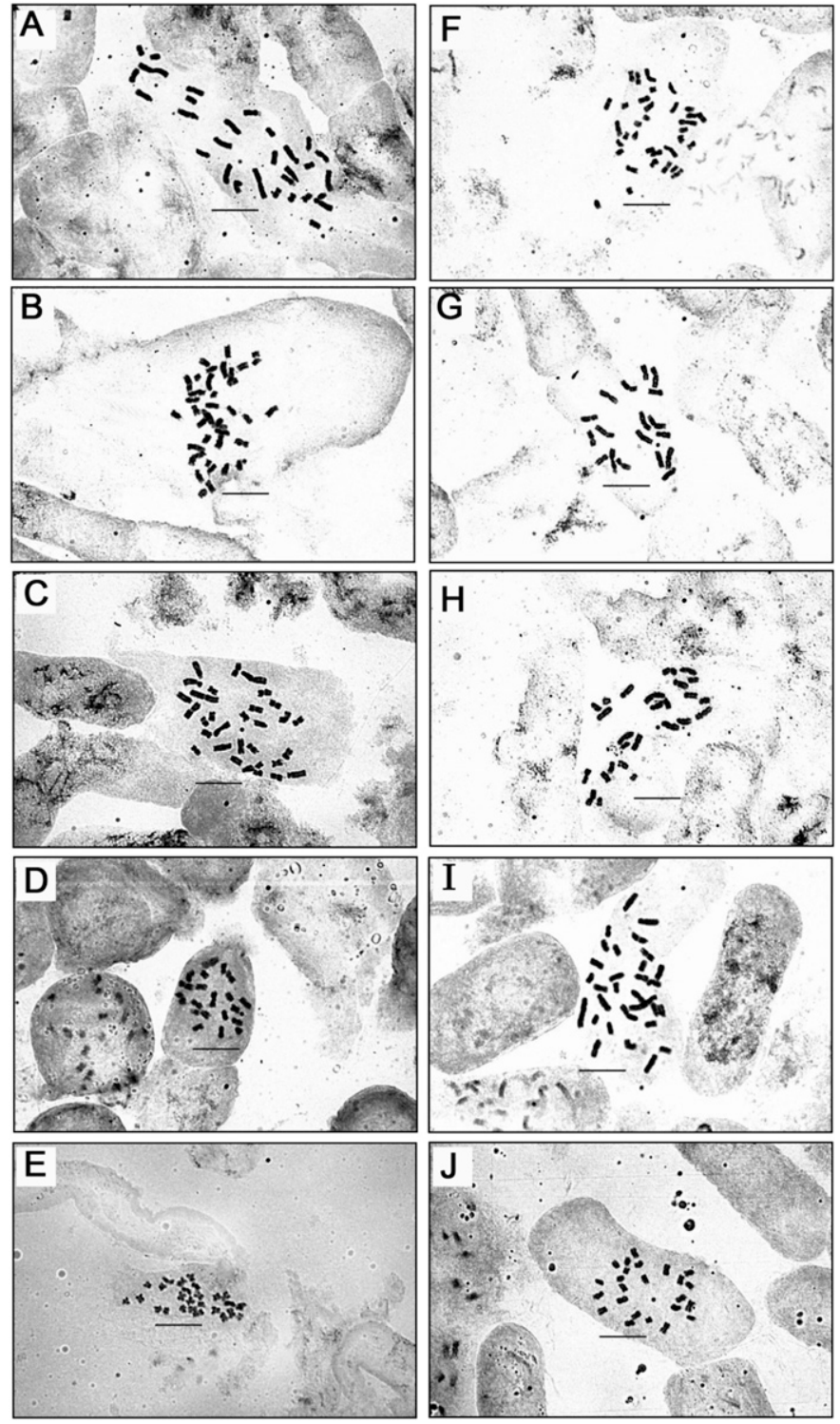

Fig. 3. Micrographs $(\times 1000)$ of somatic chromosome spreads from root tip meristematic tissue and aceto-carmine staining. (A) Caladium bicolor $(2 n=$ $30),(\mathbf{B})$ C. clavatum $(2 n=38),(\mathbf{C}) C$. $\times$ hortulanum 'Aaron' $(2 n=30),(\mathbf{D}) C$. humboldtii $(2 n=20)$, (E) C. lindenii $(2 n=26),(\mathbf{F})$ C. marmoratum $(2 n=34)$, (G) C. picturatum $(2 n=18)$, (H) C. praetermissum, $(2 n=26)$, (I) $C$. schomburgkii $(2 n=30)$, and $(\mathbf{J})$ C. steudneriifolium $(2 n=24)$; scale bar $=$ $10 \mu \mathrm{m}$.

same $2 n=30$ chromosome number with $C$. $\times$ hortulanum and most $C$. bicolor accessions.

Two $C$. clavatum accessions had the largest chromosome number in the genus, $2 n=38$, followed by two $C$. marmoratum accessions (2000-0005A and 2000-0006A) with $2 n=34$ chromosomes. The nine $C$. picturatum accessions had the smallest chromosome numbers in the genus, $2 n=18$. Two of the C. picturatum accessions also had some $2 n=20$ cells and were thus cytologically chimeric. The second smallest chromosome number, $2 n=20$, was observed in three $C$. humboldtii accessions. Caladium lindenii and $C$. praetermissum accessions shared the same chromosome number of $2 n=26$. All five $C$. steudneriifolium accessions shared the same chromosome number of $2 n=24$, although their $2 \mathrm{C}$ genome size varied by $60 \%$.

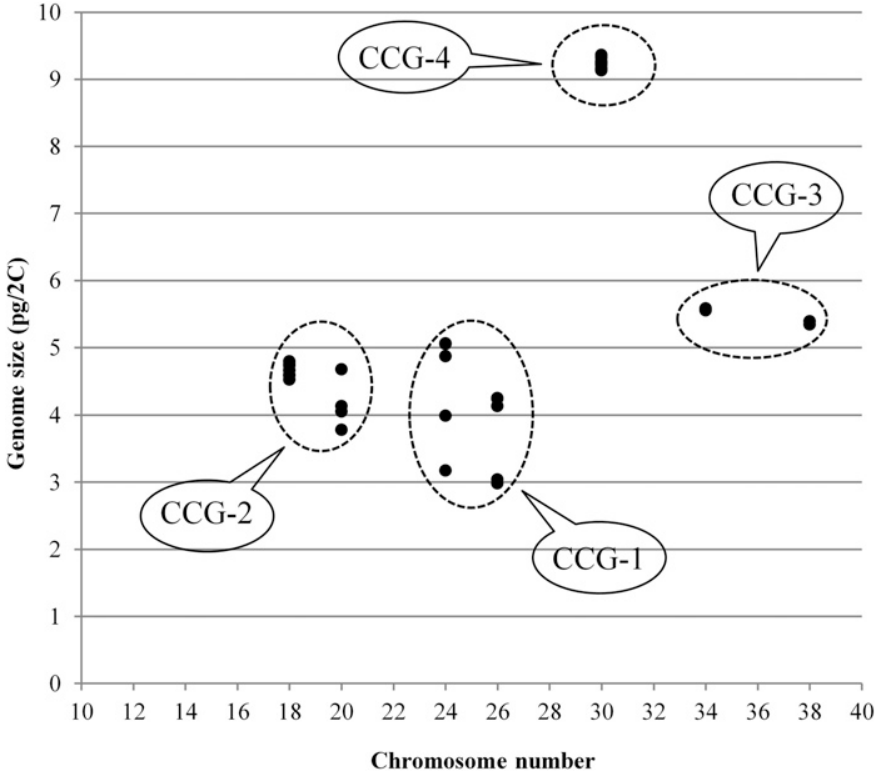

Fig. 4. Scatterplot of chromosome numbers (x-axis) and $2 \mathrm{C}$ genome sizes (yaxis) of 39 caladium accessions representing 10 species. The caladium accessions seem to fall into four Caladium cytotype groups (CCG-1 to -4). The CCG-1 contained all $C$. lindenii, $C$. praetermissum, and $C$. steudneriifolium accessions with $2 n=26$ or 24 chromosomes and a genome size between 2.97 and $5.06 \mathrm{pg} / 2 \mathrm{C}$; the CCG-2 consisted of all $C$. humboldtii and $C$. picturatum accession and one " $C$. bicolor" accession (1983-0535A) with $2 n=$ 20 or 18 and a genome size between 3.78 and $4.79 \mathrm{pg} / 2 \mathrm{C}$; the CCG-3 contained all $C$. clavatum and $C$. marmoratum accessions with $2 n=38$ or 34 and a genome size between 5.39 to $5.58 \mathrm{pg} / 2 \mathrm{C}$; and the CCG-4 was made up of all $C$. Xhortulanum cultivars and all $C$. schomburgkii accessions and four C. bicolor accessions with $2 n=30$ and a genome size between 9.13 and 9.26 $\mathrm{pg} / 2 \mathrm{C}$.

A scatterplot of chromosome number vs. genome size for 39 caladium accessions is shown in Figure 4. There was no significant linear correlation between chromosome number and genome size in these accessions. However, these accessions fall into four groups, which we refer to, for the purpose of discussion, as CCG 1 to 4 . The CCG-1 consisted of caladium accessions with $2 n=26$ ( $C$. lindenii and $C$. praetermissum) and $2 n=24$ (C. steudneriifolium). The CCG- 2 contained accessions with $2 n=20$ (C. humboldtii, and $C$. bicolor 1983-0353A) and $2 n=18$ (C. picturatum). The CCG-3 included $2 n=38$ (C. clavatum) and $2 n=34$ (C. marmoratum). The CCG-4 was composed of caladium accessions with $2 n=30$ (remaining $C$. bicolor except for accession 1983-0353A, C. ×hortulanum, and C. schomburgkii).

\section{Discussion}

Classification of Caladium species. Since Madison (1981) lumped C. marmoratum, C. picturatum, and C. steudneriifolium into $C$. bicolor, the status of the former three species has been in debate. With its unique leaf shape (long, narrow), C. picturatum has been, since then, accepted as an independent species (Croat, 1994; Mayo et al., 1997; The Plant List, 2013). However, the debate around the species status of $C$. marmoratum and C. steudneriifolium has remained. Caladium marmoratum was treated as a form of $C$. bicolor with elongate synandrodes (Hetterscheid et al., 2009) or as a synonym of $C$. bicolor (The Plant List, 2013). Similarly, C. steudneriifolium was considered 
synonymous to $C$. bicolor (The Plant List, 2013). The present study has shown that $C$. marmoratum and $C$. steudneriifolium are different from each other in chromosome number and somewhat in genome size, and they are different from $C$. bicolor in chromosome number and genome size. Both $C$. marmoratum accessions had an $\approx 40 \%$ smaller genome size and four more chromosomes than $C$. bicolor accessions; all $C$. steudneriifolium accessions had an $\approx 55 \%$ smaller genome size and six fewer chromosomes compared with $C$. bicolor accessions. Thus, chromosome number and genome size data support the separation of $C$. marmoratum and $C$. steudneriifolium from $C$. bicolor, although these three species do share similarities in leaf characteristics.

In C. steudnerifolium, two forms of plants have been recognized: those with plain green leaves and those with variegated leaves. The two forms were observed to occur in the same natural population at a ratio of approximately two (plain) to one (variegated) (Soltau et al., 2009). The whitish variegation results from irregularly shaped patches of cells without chlorophyll and the variegation mimics damage by mining moth larvae so as to avoid actual predation (Soltau et al., 2009). One C. steudneriifolium accession in this study was variegated, and three others had plain green leaves. No differences were observed between the two forms in chromosome number, but minor differences in genome size were observed.

Hetterscheid et al. (2009) introduced C. clavatum and C. praetermissum into Caladium. Caladium clavatum has been in cultivation for several decades under the name $C$. bicolor var. rubicundum or C. bicolor rubicunda (Graf, 1976). The name was initially published in 1872 but not introduced to the horticultural industry until it was used in the 1973 Edition of Graf's Exotica (Hetterscheid et al., 2009). Hetterscheid et al. (2009) elevated it to a new species based on its distinct differences from $C$. bicolor in the morphology of synandrodes, styles, peduncles, and tubers. Synandrodes of $C$. clavatum, particularly those near the bottom part of the sterile male flower zone on the spadix, have a short (1 to $3 \mathrm{~mm}$ ) stalk-like base, whereas synandrodes of $C$. bicolor are sessile. In addition, $C$. clavatum has fused styles, peduncles shorter than the petioles, gives out a strong, sweet scent during female anthesis, and produces rhizomatous offsets on tubers. The present study has shown that $C$. clavatum is also distinct from $C$. bicolor in genome size and chromosome number, supporting the species status of $C$. clavatum.

Caladium praetermissum has been in cultivation for decades in Europe and in the United States under the name Alocasia (Schott) G. Don 'Hilo Beauty'. The species is similar to $C$. bicolor in general habit and leaf morphology but differs from $C$. bicolor in its pale green leaf blades with large, white- to creamcolored spots or blotches, clavate synandrodes between female and male flowers, and thick rhizomatous stems (Hetterscheid et al., 2009). There is suspicion that $C$. praetermissum might be a sport mutation of $C$. marmoratum (Hetterscheid et al., 2009). The present study has shown that $C$. praetermissum and $C$. marmoratum are different in both genome size and chromosome number. Caladium praetermissum accessions have a smaller genome (at least 30\%) and eight chromosomes less than $C$. marmoratum accessions; thus, we conclude that the species status of $C$. praetermissum is valid. The chromosome number of $C$. praetermissum was listed as $2 n=28$ by Hetterscheid et al. (2009); however, the chromosome counts of both $C$. praetermissum accessions in the present study were $2 n=26$. When additional accessions of $C$. praetermissum are available, they need to be examined to resolve the difference between Hetterscheid et al. (2009) and this study in chromosome number.

Genome size variation in Caladium. Previously Ghosh et al. (2001) reported the genome size for one fancy-leaved caladium ( $C$. Xhortulanum 'Red Polka') at $11.0 \mathrm{pg} / 2 \mathrm{C}$ based on Feulgen densitometry. Our study increased the reported Caladium genome size estimates by an additional 63 accessions. The mean genome size of $26 \mathrm{C}$. $\times$ hortunalum cultivars was $9.23 \mathrm{pg} / 2 \mathrm{C}, \approx 16.2 \%$ smaller than the genome size reported for 'Red Polka'. No caladium accession analyzed in this study had a genome size estimate above $10 \mathrm{pg} / 2 \mathrm{C}$. The difference in genome size estimates between Ghosh et al. (2001) and the present study may be the result of the use of different caladium cultivars, staining methods, and/or instruments. Reportedly, the chromosome number of 'Red Polka' was $2 n=32$ (Sharma and Sarkar, 1964), which is two more chromosomes than the caladium cultivars used in this study. Staining methods and instruments are known to cause minor differences in genome size estimates (Doležel and Göhde, 1995). Caladium 'Red Polka' was not available in the United States, and its genome size was not determined in this study.

Accession 1983-0353A was collected from Brazil and had been tentatively placed under $C$. bicolor based on its morphology. However, this accession had a genome size approximately half that of other $C$. bicolor accessions and 10 fewer chromosomes $(2 n=20)$. In a previous molecular marker analysis, this accession did not cluster with other $C$. bicolor accessions (Deng et al., 2007). Together these data raise the following question: does this accession represent a misclassified distinct species? Currently the number of plants maintained at the MSBG for this accession is very limited, and more detailed studies are not possible. A broader sampling of plants from the Brazilian locality where 1983-0353A was collected is necessary to determine its status and relationships within the genus.

Chromosome number variation in CALADium. The present study provided the first chromosome number report for four caladium species, C. clavatum, C. marmoratum, C. picturatum, and $C$. steudnerifolium. This study also produced new information about the chromosome numbers of four other caladium species, C. humboldtii, $C$. lindenii, $C$. praetermissum, and $C$. schomburgkii. Five chromosome numbers $(2 n=18,20,24,34$, and 38 ) observed in this study were new to Caladium.

Chromosome counting efforts for fancy-leaved caladium (C. $\times$ hortulanum) cultivars can be traced back to Jones (1957) and Pfitzer (1957). Jones (1957) indicated $2 n=30$ chromosomes for cultivars Autumn Sunset, Marie Moir, and Rose Beasty. Pfitzer (1957) reported $n=15$ for cultivars Porto Rico, Scarlet Pimpernel, and Triomphe de l'Exposition and $n=15$ and $2 n=30$ for O.V. Zagen. Sharma and Sarkar (1964) extended chromosome counting effort to 17 other caladium cultivars and observed $2 n=30$ in seven cultivars, but also $2 n=28$ in four cultivars including 'Lord Derby' and $2 n=32$ in six cultivars including 'Candidum' and 'Red Polka'. However, Marchant (1971) reported $2 n=30$, rather than $2 n=28$, for 'Lord Derby'. More diverse chromosome numbers were reported by Sarkar (1986) when he examined 32 caladium cultivars: $2 n=26$ in three cultivars, $2 n=28$ in 16 cultivars, $2 n=30$ in 12 cultivars, and $2 n=32$ in one cultivar. Two of the cultivars Sarkar examined ('Scarlet Pimpernelle' and 'Triomphe de 1'Exposition') were also examined by Pfitzer (1957). The two authors reported the same chromosome number for 'Scarlet Pimpernelle' $(2 n=30)$ but different chromosome numbers for 
'Triomphe de l'Exposition' (Pfitzer: $n=15$, Sarkar: $2 n=28$ ). The present study examined 119 cells from six caladium cultivars and found $2 n=30$ chromosomes in these cultivars. One of the six cultivars was Candidum, and 30 of its 31 root cells observed showed $2 n=30$ rather than $2 n=32$ as reported by Sharma and Sarkar (1964). When previous and current chromosome number reports for caladium cultivars $(C$. $\times$ hortulanum) were combined, $2 n=30$ seemed to be most prominent, present in 32 cultivars, followed by $2 n=28$ in 21 cultivars, $2 n=32$ in seven cultivars, and $2 n=26$ in 3 cultivars (Jones, 1957; Marchant, 1971; Pfitzer, 1957; Sarkar, 1986; Sharma and Sarkar, 1964).

Several previous reports showed $2 n=30$ chromosomes for C. bicolor (Kurakubo, 1940; Marchant, 1971; Ramachandran, 1978; Simmonds, 1954, Subramanian and Munian, 1988), and one report showed $n=15$ from bivalent counts in $C$. bicolor pollen mother cells (Pfitzer, 1957; Ramachandran, 1978). Results from the present study were in agreement with the previous reports except for the accession 1983-0353A that might represent a misclassified distinct species.

Caladium humboldtii is unique compared with other caladium species: plants are miniature (less than $25 \mathrm{~cm}$ tall) with many blotches on tiny green leaves (less than $10 \mathrm{~cm}$ long, less than $5 \mathrm{~cm}$ wide). It was suspected to be a chromosomal race of C. bicolor (Madison, 1981), but subsequent molecular marker analysis showed that $C$. humboldtii was genetically distinct from C. bicolor (Deng et al., 2007; Loh et al., 1999). Pfitzer (1957) reported $2 n=19$ chromosomes for this species. However, all three $C$. humboldtii accessions examined in this study had $2 n=$ 20 chromosomes.

The first report of $C$. lindenii chromosome number was under the name Xanthosoma lindenii (André) T. Moore by Pfitzer (1957), who observed 13 bivalents in the pollen mother cells. Subsequently, Sharma (1970) reported $2 n=28$ for this species. In this study, both $C$. lindenii accession had $2 n=26$ chromosomes, consistent with Pfitzer's observation but different from Sharma's. C. praetermissum was a new species to Caladium; Hetterscheid et al. (2009) indicated $2 n=28$ for this species. Both $C$. praetermissum accessions in this study had $2 n=26$ chromosomes. Previously reported chromosome numbers for $C$. schomburgkii all came from examining the cultivar Changjur. Jones (1957) reported $2 n=28$, whereas Sarkar (1986) observed $2 n=28,30$, and 18 chromosomes in 'Changjur'. However, we observed only $2 n=30$ in 30 cells of 'Changjur' and two $C$. schomburgkii accessions collected from Ecuador.

In summary, differences existed in chromosome counts by different reports of the same species or cultivars. One chromosome difference occurred in C. humboldtii $(2 n=19$ or 20$)$, and two chromosome number differences occurred in three caladium cultivars [Candidum $(2 n=30$ or 32$)$, Lord Derby $(2 n=28$ or 30$)$, and Triomphe de l'Exposition $(2 n=28$ or $n=15)]$ and three species [C. lindenii $(2 n=26$ or 28$), C$. praetermissum $(2 n=$ 26 or 28$)$, and $C$. schomburgkii 'Changjur' $(2 n=28$ or 30$)]$. One possible explanation for the variability within certain cultivars could be the presence of $\mathrm{B}$ chromosomes in caladiums. B chromosomes have been reported for numerous species in seven genera of Araceace, including Anthurium Schott, Schismatoglottis Zoll. \& Moritzi, and Typhonium Schott (Okada, 1992; Sheffer and Croat, 1983; Sousa et al., 2014). In Schismatoglottis irrorata Engl., the number of B chromosomes varied not only among individuals but also within the same root tips (Okada, 1992). The round and small extra chromosome observed in one of the root tip cells of 'Candidum' and 'Miss Muffet' in this study seemed to like B chromosomes described in the literature, but more cytological work is needed to confirm or rule out the presence of B chromosomes in caladiums. Future studies may focus on examining meiotic behaviors of chromosomes in those caladium species and cultivars that have shown variable chromosome numbers and comparing the phenotype of these caladium accessions in well-controlled environments to understand the phenotypic effects of extra chromosomes.

POSSIBLE MODES OF GENOME SIZE AND CHROMOSOME NUMBER Evolution in CALADIUM. The genera Caladium and Xanthosoma are closely related (Croat, 1994). Based on plant morphological and anatomical data, Madison (1981) considered caladium species to have evolved from a Xanthosoma-like ancestor. According to the IPCN, the majority of Xanthosoma species have $2 n=26$ chromosomes (Goldblatt and Johnson, 1979). Using a maximum likelihood approach and chromosome counts for aroid species, Cusimano et al. (2012) inferred the basic chromosome number $n=13$ for Caladium, Xanthosoma, and closely clustered genera. These pieces of information prompted us to consider two caladium species with $2 n=26$ (i.e., $C$. lindenii and C. praetermissum) as possible ancestors of other caladium species. In a recent molecular marker analysis, $C$. lindenii was placed at the very base of a dendrogram of caladium species, far from other caladium species (Deng et al., 2007). Caladium praetermissum was not included in the analysis. Morphologically, C. praetermissum, and particularly $C$. lindenii, look substantially different from other caladium species, but $C$. steudneriifolium $(2 n=24$, genome size $=3.17$ to $5.06 \mathrm{pg} / 2 \mathrm{C})$ seems to be more close to other caladium species in leaf and plant appearance. We suspect that $C$. steudneriifolium might be a more direct ancestor of other caladium species (excluding C. lindenii and C.praetermissum) and that C. steudneriifolium might have evolved from species with $2 n=26$, probably through chromosome rearrangements and losses. Similarly, chromosome rearrangements and losses, in addition to other factors, might have played significant roles in the formation of C. humboldtii and C. picturatum, both in the CCG-2 group and with the lowest chromosome numbers in the genus.

The genome size of the CCG-4 species ( $C$. bicolor, $C$. schomburgkii, and the $C$. $\times$ hortulanum) is approximately twice the genome size of the CCG-2 species ( $C$. humboldtii and $C$. picturatum). This genome size relationship seems to suggest a past duplication from those of the CCG- 2 species. The chromosome number of the CCG-3 species $(2 n=34$ in $C$. marmoratum and $2 n=38$ in $C$. clavatum) was close to twice the chromosome number of the CCG- 2 species $(2 n=18$ or 20 in C. humboldtii and $C$. picturatum), which suggests a possible chromosome doubling or polyploidization in these CCG-3 species. However, when genome size and chromosome number were both considered, conflicts emerged as for how caladium genome size and chromosome number had evolved in Caladium. For example, the putatively "tetraploidized" C. marmoratum and $C$. clavatum (CCG-3) did not show an expected, doubled genome size $(8.98 / 2 \mathrm{C})$; rather, their genome sizes are only $\approx 15 \%$ to $40 \%$ larger than those of $C$. humboldtii and $C$. picturatum in CCG-2. Conversely, C. bicolor and C. schomburgkii in CCG-4 contain a putatively "duplicated" genome based on genome size but do not show an expected, doubled chromosome number $(2 n=36$ or 40$)$. What occurred in the apparently "tetraploidized" genome of C. clavatum and C. marmoratum (CCG-3) or the "duplicated" genome of C. bicolor and C. schomburgkii (CCG-4) that have caused the observed disagreement between 
chromosome number and genome size in these species? Although there may be a multitude of possible explanations, we hypothesize that numerous chromosome fusions/losses may have occurred after the speculated genome duplication event in the formation of $C$. bicolor and C. schomburgkii in the CCG-4 and lowered their chromosome number to $2 n=30$. Similarly, we hypothesize that dramatic chromosome rearrangements and DNA losses might have occurred after the speculated tetraploidization event in the formation of $C$. clavatum and $C$. marmoratum in the CCG-3. Similar speculations had been made in Typhonium, another genus of Araceae that exhibits a wide range of somatic chromosomes (Sousa et al., 2014). A recent study using molecular phylogeny and cytogenetic tools has confirmed the important roles of chromosome rearrangements and polyploidization in the evolution of species in Typhonium (Sousa et al., 2014). Similar studies are needed in caladium, which should provide very valuable information to understand the possible roles of genome duplication or polyploidization, chromosome rearrangements, and chromosome losses in caladium speciation.

IMPLICATIONS FOR PRESERVATION OF CALADIUM DIVERSITY AND CALADIUM BREEDING. The present study suggests that caladium species are cytologically very diverse and some caladium accessions may look similar morphologically but differ in chromosome number or genome size. Although the significance of this cytological diversity to the evolution of caladiums remains to be understood, it may be worth preserving germplasm for future studies and practical applications. Several botanical gardens in the United States collected and maintained caladiums. The cytological diversity in these collections might be greater than expected from morphological observations. There may be even a greater level of cytological diversity in the natural populations of caladiums in South and Central America where the genus originated. Future collection efforts in these regions may be warranted.

It was suspected that $C$. bicolor, $C$. marmoratum, $C$. picturatum, and $C$. schomburgkii had contributed to the development of fancy-leaved caladium (C. Xhortulanum) cultivars. All six cultivars examined in this study have the same chromosome number as $C$. bicolor and $C$. schomburgkii, supporting a major role for these two species in historical caladium breeding. It appears unlikely that $C$. picturatum has played any direct roles in the origin of $C$. $\times$ hortulanum cultivars because of the large differences between $C$. picturatum and $C$. bicolor or $C$. schomburgkii in both chromosome number and genome size. The role of $C$. marmoratum may also be ruled out. Should this species have been deliberately hybridized with $C$. bicolor or $C$. schomburgkii, their progeny would be expected to have $2 n=32$ chromosomes and a genome size of $\approx 7.40 \mathrm{pg} / 2 \mathrm{C}$. None of the $24 \mathrm{C}$. $\times$ hortulanum cultivars examined has a genome size close to this value.

Because of their unique leaf color and shape, C. clavatum and $C$. picturatum have been of particular interest for use in modern caladium breeding. This study has shown that both species are very different from the widely cultivated $C$. $\times$ hortulanum or C. bicolor and C. schomburgkii in chromosome number and genome size; thus, progeny of direct crosses between $C$. clavatum or $C$. picturatum and $C$. $\times$ hortulanum, C. bicolor or C. schomburgkii (if such crosses are compatible) may be sterile, preventing backcrosses. Future efforts attempting to introgress traits from $C$. clavatum or $C$. picturatum may need to focus on developing and selecting novel $F_{1}$ hybrids.
Such hybrids could be commercially propagated through tuber division or tissue culture provided that they express desirable, novel plant, foliar, or tuber traits.

\section{Literature Cited}

Bennett, M.D. and I.J. Leitch. 2012. Plant DNA C-values database. 27 Apr. 2014. <http://data.kew.org/cvalues/CvalServlet?querytype=1>. Birdsey, M.R. 1951. The cultivated aroids. Gillick Press, Berkeley, CA.

Croat, T.B. 1994. Taxonomic status of neotropical Araceae. Aroideana 17:33-60.

Cui, L., P.K. Wall, J. Leebens-Mack, B.G. Lindsay, D.E. Soltis, J.J. Doyle, and P.S. Soltis. 2006. Widespread genome duplications throughout the history of flowering plants. Genome Res. 16:738-749.

Cusimano, N., A. Sousa, and S.S. Renner. 2012. Maximum likelihood inference implies a high, not a low, ancestral haploid chromosome number in Araceae, with a critique of the bias introduced by ' $x$ '. Ann. Bot. (Lond.) 109:681-692.

Deng, Z., F. Goktepe, and B.K. Harbaugh. 2007. Assessment of genetic diversity and relationships among caladium cultivars and species using molecular markers. J. Amer. Soc. Hort. Sci. 132:219-229.

Deng, Z. and B.K. Harbaugh. 2006. 'Garden White'-A large white fancy-leaved caladium for sunny landscapes and large containers. HortScience 41:840-842.

Doležel, J. and W. Göhde. 1995. Sex determination in dioecious plants Melandrium album and M. rubrum using high-resolution flow cytometry. Cytometry 19:103-106.

Doležel, J., J. Greilhuber, and J. Suda. 2007. Estimation of nuclear DNA content in plants using flow cytometry. Nat. Protoc. 2:22332244.

Ghosh, P., S. Mukherjee, and A.K. Sharma. 2001. Cytophotometric estimation of in situ DNA content in several species of Araceae. Cytobios 105:177-183.

Goldblatt, P. and D.E. Johnson. 1979. Index to plant chromosome numbers. Missouri Botanical Garden, St. Louis, MO

Graf, A.B. 1976. Exotica, series 3: Pictorial cyclopedia of exotic plants from tropical and near-tropical regions. 9th Ed. Roehrs, Rutherford, NJ.

Guerra, M. 2008. Chromosome numbers in plant cytotaxonomy: Concepts and implications. Cytogenet. Genome Res. 120:339-350.

Hayward, W. 1950. Fancy-leaved caladiums. Plant Life 6:131-142.

Hetterscheid, W.L.A., J. Bogner, and J. Boos. 2009. Two new Caladium species (Araceae). Aroideana 32:126-131.

Huxley, A., M. Griffiths, and M. Levy. 1992. The new Royal Horticultural Society dictionary of gardening. MacMillan Press, London, UK.

Jones, E.J. 1957. Chromosome number and phylogenetic relationships in the Araceae. PhD diss., Univ. Virginia, Charlottesville, VA.

Kurakubo, Y. 1940. Über die chromosomenzahlen von Araceae-Arten. Bot. Zool. 8:1492 (cited from Pfitzer, 1957).

Leong-škorničkova, J.L., O. Šída, V. Jarolímová, M. Sabu, T. Fér, P. Trávníček, and J. Suda. 2007. Chromosome numbers and genome size variation in Indian species of Curcuma (Zingiberaceae). Ann. Bot. (Lond.) 100:505-526.

Loh, J.P., R. Kiew, A. Kee, L.H. Gan, and Y.Y. Gan. 1999. Amplified fragment length polymorphism (AFLP) provides molecular markers for the identification of Caladium bicolor cultivars. Ann. Bot. (Lond.) 84:155-161.

Loureiro, J., P. Trávníček, J. Rauchová, T. Urfus, M. Štech, S. Castro, and J. Suda. 2010. The use of flow cytometry in the biosystematics, ecology and population biology of homoploid plants. Preslia 82:3-21.

Madison, M. 1981. Notes on Caladium (Araceae) and its allies. Selbyana 5:342-377.

Marchant, C.J. 1971. Chromosome variation in Araceae: III Philodendreae to Pythonieae. Kew Bull. 25:323-329.

Mayo, S.J., J. Bogner, and P.C. Boyce. 1997. The genera of Araceae. Royal Botanic Gardens, Kew, London, UK. 
Okada, H. 1992. Population diversity of Schismatoglottis irrorata (Araceace) at Malesian wet tropics with reference to the distribution of B chromosomes. Cytologia (Tokyo) 57:401-407.

Petersen, G. 1989. Cytology and systematica of Araceae. Nord. J. Bot. 9:119-166.

Pfitzer, P. 1957. Chromosomenzahlen von Araceen. Chromosoma 8:436-446.

Praça-Fontes, M.M., C.R. Carvalho, and C.D. Cruz. 2011. Revisiting the DNA C-value of the genome size-standards used in plant flow cytometry to choose the 'best primary standards'. Plant Cell Rpt. 30:1183-1191.

Ramachandran, K. 1978. Cytological studies on South Indian Araceae. Cytologia (Tokyo) 43:289-303.

Sarkar, A.K. 1986. Mode of evolution in Caladium bicolor (Ait.) Vent. (Araceae). Biol. Zent. B1. 105:621-639.

Sharma, A.K. 1970. Annual report, 1967-1968. Res. Bul. Univ. Calcutta (Cytogenet. Lab.) 2:1-50 (cited from Petersen, 1989).

Sharma, A.K. and A.K. Sarkar. 1964. Studies on the cytology of Caladium bicolor with special reference to the mode of speciation. Genetica Iberica 16:21-47 (cited from Petersen, 1989).
Sheffer, R.D. and T. Croat. 1983. Chromosome numbers in the genus Anthurium (Araceae) II. Amer. J. Bot. 70:858-871.

Simmonds, N.W. 1954. Chromosome behaviour in some tropical plants. Heredity 8:139-146.

Soltau, U., S. Dötterl, and S. Liede-Schumann. 2009. Leaf variegation in Caladium steudneriifolium (Araceae): A case of mimicry? Evol. Ecol. 23:503-512.

Sousa, A., N. Cusimano, and S.S. Renner. 2014. Combining FISH and model-based prediction to understand chromosome evolution in Typhonium (Araceae). Ann. Bot. (Lond.). 113:669-680. doi: 10.1093/aob/mct302.

Subramanian, D. and M. Munian. 1988. Cytotaxonomical studies in South Indian Araceae. Cytologia (Tokyo) 53:59-66.

Suda, J. and I.J. Leitch. 2010. The quest for suitable reference standards in genome size research. Cytometry 77A:717-720.

The Plant List. 2013. Version 1.1. 27 Apr. 2014. <http://www.theplantlist. org $/$ tpl1.1/search?q=caladium $>$.

Wilfret, G.J. 1993. Caladium, p. 239-247. In: de Hertogh, A. and M. le Nard (eds.). The physiology of flower bulbs. Elsevier, New York, NY. 